（9）依田連平，佐藤有一，真下美佐男，山内 勘：日本 金属学会誌, $34(1970), 526$.

(10) 平 修二編：金属材料の高温強度，美堅堂, (1968), 37.

(11) P.N.Randa11 : Proc. ASTM, 60 (1960) , 885.

(12) C.E.Birchenall and R.E.MehI : Trans. AIME, $188(1950), 144$

(13) 松島成夫：材料，15(1966)，37.
（14）松島成夫：材料，11(1967)，89：機峨学会論文集, $33(1967), 327$.

(15) T.Yamashita and Y.Taneda: Jap. J.Appl. Phys., 2(1963), 266.

(16) 松島成夫：日本金属学会誌，42(1978)，75.

（17）たと充ば，(10)のp.11；F.Garofalo(足立訳)：金 属クリープの基礎, 丸善, (1968), 50 .

\title{
黒鉛分散 $\mathrm{Al}$ および $\mathrm{Cu}$ 鋳造合金の減衰能*
}

\section{大貫 化** 添野 浩** 諏訪正輝**}

Jin Onuki, Kô Soeno and Masateru Suwa : Damping Capacity of Graphite-dispersed $\mathrm{Al}$ and $\mathrm{Cu}$ Casting Alloys. $\quad \mathrm{Al}$ and $\mathrm{Cu}$ casting alloys were produced with variations in quantity $(0 \sim 24$ vol\%) and size $(177 \sim 900 \mu \mathrm{m})$ of graphite particles and in matrix composition in order to determine their effect on the damping capacity. The damping capacity $Q^{-1}$ of graphite-dispersed $\mathrm{Al}$ and $\mathrm{Cu}$ casting alloys has been investigated in transverse vibration in the temperature range from room temperature to $150^{\circ} \mathrm{C}$. The results obtained are as follows. (1) The damping capacity $Q^{-1}$ of graphite-dispersed $\mathrm{Al}$ and $\mathrm{Cu}$ casting alloys increases with increasing graphite content and this is independent of matrix composition. (2) Al casting alloy containing 23 vol\% graphite and $\mathrm{Cu}$ casting alloy containing $16 \mathrm{vol} \%$ graphite exhibits damping capacity $Q^{-1}$ of $6 \times 10^{-3}$ and $4 \times 10^{-3}$, respectively. (3) The damping capacity $Q^{-1}$ of $\mathrm{Al}$ and $\mathrm{Cu}$ casting alloys depends on the graphite size and increases as the graphite size increases. (4) The temperature dependence of the damping capacity $Q^{-1}$ in graphite-dispersed $\mathrm{Al}$ and $\mathrm{Cu}$ casting alloys is small.

(Received April 7, 1979)

\section{I. 緒言}

構造物あるいは機械の振動を減衰能の高い材料を用いて 防止しょうといら試みがなされている。從来から知られて いる減亭能の高い合金には (1) Mn-Cu 系合金 ${ }^{(1)(2)}, \mathrm{Cu}$ A1-Ni 系合金 ${ }^{(3)}$, Ti-Ni 合金 ${ }^{(4)}$. (2) $12 \%$ Cr 鋼 ${ }^{(5)}$. (3) 片状黑鉛鋳鉄 (6) (11)，Al-Zn 合金 ${ }^{(12)}$. (4) $\mathrm{Mg}-\mathrm{Zr}$ 合金 ${ }^{(13)}$ $\mathrm{Mg}-\mathrm{Mg}_{2} \mathrm{Ni}$ 合金 ${ }^{(14)}$ 等があり，減衰機構から(1)は双晶 型，(2)は強磁性型，(3)は複合型，(4)は転位型と呼ば れている(15)，強磁性型に属する減衰能の高い合金として， 最近增本らは $\mathrm{Fe}-\mathrm{Mo}$ 系合金 ${ }^{(16)}$ 放よび $\mathrm{Fe}-\mathrm{Co}$ 系合金 ${ }^{(17)}$ 見出した。る上記のいずれ炕属さないが，ステンンス 鋼炕粒界腐食を施した高減衰能合金 ${ }^{(18)}$ も見出されている. さらに $\mathrm{Al}$ 合金中に黒鉛を体積比で $4 \%$ 程度分散させた鋳 造合金も，減衰能がかなり高いと報告されている(19).

一方，著者らは黒鉛を体積比で $20 \%$ 程度分散させた A1 打よび $\mathrm{Cu}$ 鋳造合金が乾式摩擦下に打いて優れた柇摩耗性 を示すことを既に報告したが(20)〜(22)，これらの合金も高 い減衰能を示すことが期待される。減衰能が高ければ耐摩 耗性を必要とするような騷音, 振動源の部材として有効で あると考文，黑鉛分散 $\mathrm{Al}$ 出上び $\mathrm{Cu}$ 鋳造合金の減哀能に

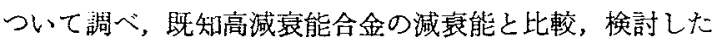
のでその結果を報告する。

\section{II. 実 験 方 法}

\section{1. 試料の作製方法}

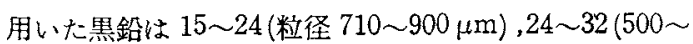
$710 \mu \mathrm{m}), 32 \sim 60(250 \sim 500 \mu \mathrm{m}), 60 \sim 80(177 \sim 250 \mu \mathrm{m}) \times$ ッシニに分粒した天然黒鉛破破粉である。形状は Photo.1 に示すように角ばって括り，几き開面も謋められ，鱗状黑 鉛よりも厚みがあることが特徽である。これらの黑鉛に無 電解メッキ法で前報同様 $\mathrm{Cu}^{(20)(21)}$ 西るいは $\mathrm{Ni}$ を被覆した が, 前者は $\mathrm{Cu}$ 合金, 後者は $\mathrm{Al}$ 合金への黒鉛の分散を容易 にするために行った。ささらにメッキした黒鉛を $\mathrm{Cu}$ 蛙よび Al 合金溶湯中にそれぞれ体積比で 0 20\% となるように 添加し，61.7 MPa で加仕しつつ高压鋳造凝固させ $30 \times 50$ $\times 150(\mathrm{~mm})$ の鋳媿を作製した。Cu 扰よび Al 合金の組成 としては黒鉛を分散したときの耐摩耗性が特に優れている $\mathrm{Cu}-5 \% \mathrm{Sn}-5 \% \mathrm{Zn}-4 \% \mathrm{~Pb}-0.8 \mathrm{Ti}$ 合 金 ${ }^{(21)(22)}, \mathrm{Al}-12 \% \mathrm{Si}-$ $3 \% \mathrm{Cu}-0.3 \% \mathrm{Mg}$ 合金 ${ }^{(20)}$ を選んだ。な 黒鉛添加時儿黒鉛粒子表面の Ni が溶出して合金化され， 
黑鉛涯加量が体積比で $20 \%$ の場合 $\mathrm{A} 1$ 合金中の $\mathrm{Ni}$ 含有量 が約 4.7\% になる.Photo.2 にこれらの合金中に粒径 24 〜32 メッシュの黑鉛を体積比で16〜20\% 分散した後の組

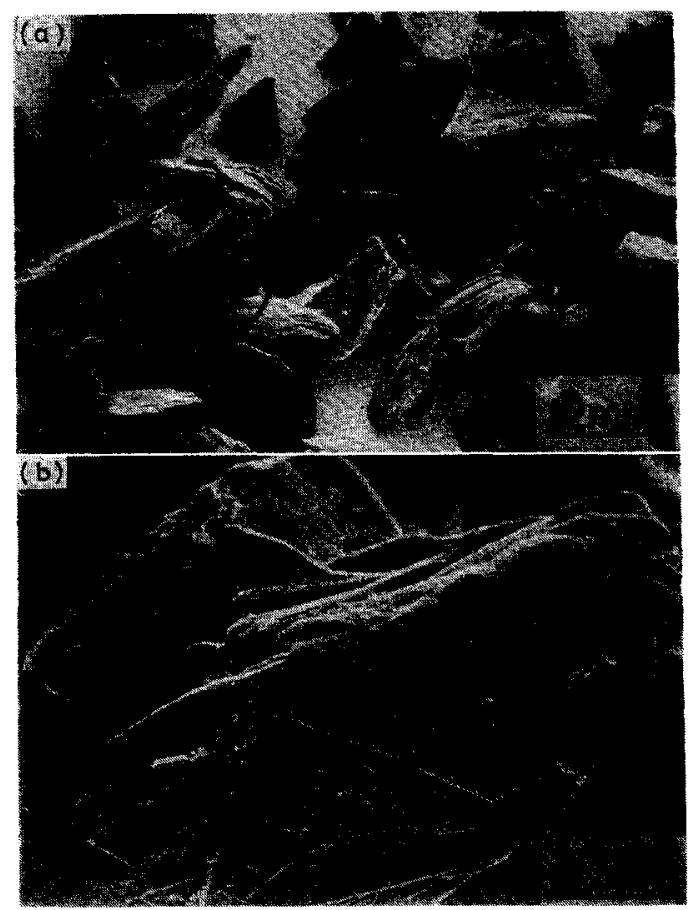

Photo.1 Appearance of graphite.

(b) : magnification of encircled region of (a).

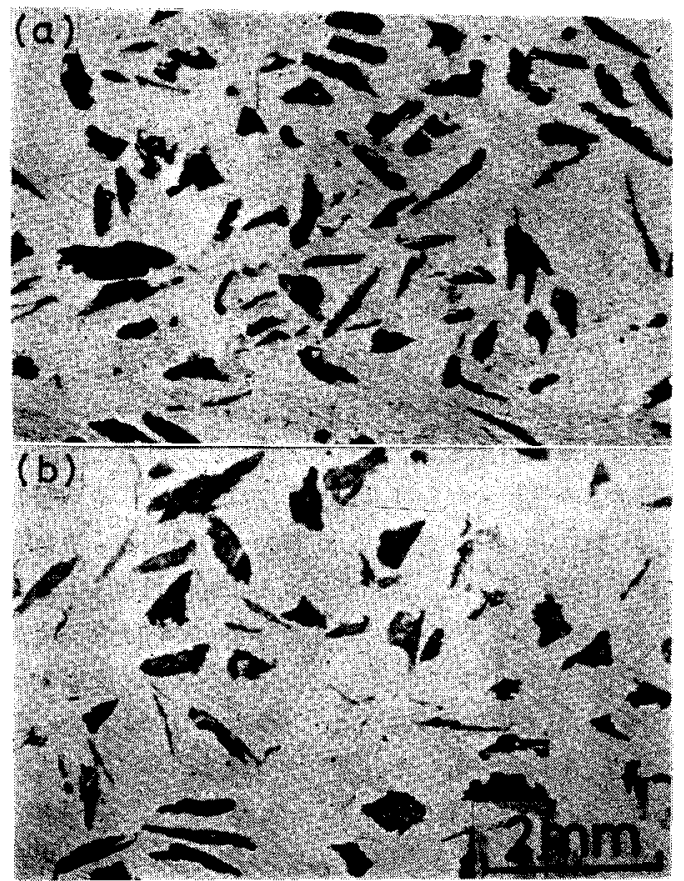

Photo.2 Microstructure of graphite-dispersed Al and $\mathrm{Cu}$ casting alloys.

(a) $\mathrm{A} 1-4.7 \% \mathrm{Ni}-12 \% \mathrm{Si}-3 \% \mathrm{Cu}-0.3 \% \mathrm{Mg}-20$ vol\% $\mathrm{C}$.
(b) $\mathrm{Cu}-5 \% \mathrm{Sn}-5 \% \mathrm{Zn}-4 \% \mathrm{~Pb}-0.8 \% \mathrm{Ti}-16$ vol\%
織を示ず，黑鉛はいずれも端部は角ばっており，鋳熄中に

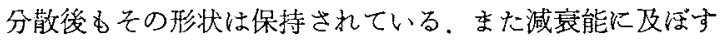
合金組成の影響を茼べる目的で Cu- $27.5 \% \mathrm{Mn}, \mathrm{Cu}-5 \% \mathrm{Sn}$ $5 \% \mathrm{Zn}-0.8 \% \mathrm{Ti}, \mathrm{Al}, \mathrm{Al}-12 \% \mathrm{Si}$ 合金中にも同様汇黑鉛を 分散した鋳塊を作製した，次に黑鉛を分散した鋳塊から $5 \times 2 \times 120(\mathrm{~mm})$ の減衰能測定用の試料を切り出したが， 切削歪を除去するために $300 \sim 400^{\circ} \mathrm{C}$ の温度で $1 \mathrm{~h}$ 加熱し 空冷した。減衰能測定用試料中の黑鉛量はリニアルフナり シス ${ }^{(23)}$ にりその量を確認した。なお減衰能の高い合金 としては同様な形状に加工した $65 \% \mathrm{Mn}-35 \% \mathrm{Cu}$ 鋳造合金 おょび片状黑鉛鋳鉄 FC10，FC25 を選んだ。

\section{2. 装置と測定方法}

減衰能測定用横振動装置の概略を Fig.1 1 示す。回路 は試料の共振周波数で発振する自励発振方式で, 試料の駆 動,ピックアップとも静電方式で行った。 スタート，ストッ プ回路の信号で别振を止め, 検出回路からの出力を波高検 出器に入れ，振幅が最初の掁幅の $\exp (-\pi / 5)$ なる值に減 衰するをでの波数を数えて内部摩擦 $Q^{-1}(=\delta / \pi)$ を求めた。 ここで $\delta$ は対数減衰率で势る. $5 \times 2 \times 120(\mathrm{~mm})$ の試料を 振動の節に相当する部分で $\phi 0.15 \mathrm{~mm}$ の焼鈍した $\mathrm{Ni}$ 線 で吊り，さらに同一寸法の試料熱電対を点溶接したもの をならべて和き，この温度を $Q^{-1}$ 測定用陚料の温度とし た。をた試料全体の温度不均一をできるだけ少なくするた

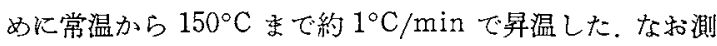
定槽内は $10^{-3} \mathrm{mmHg}$ に排気して专り，測定の祭試料表面 に発生する最大歪は $10^{-6}$ のオーダである。

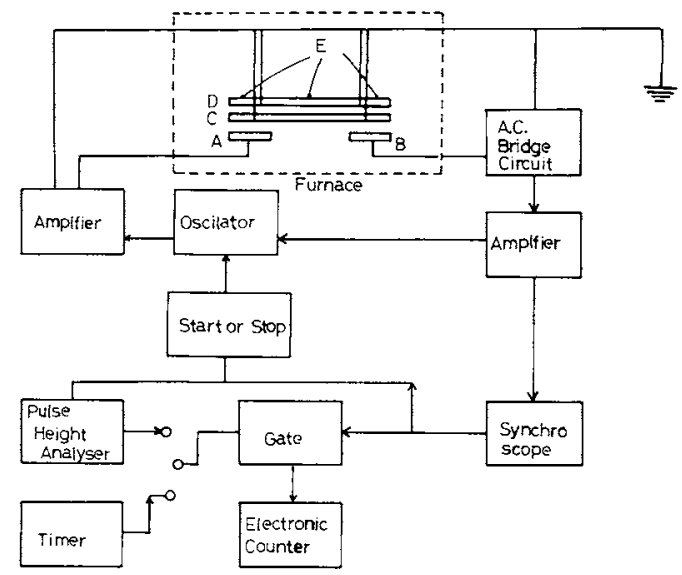

A : Driving electrode, B : Pick-up electrode, $\mathrm{C}$ : Specimen for measuring $Q^{-1}, \quad \mathrm{D}$ : Specimen for measuring temperature, $\mathrm{E}$ : Thermocouples Fig. I Block diagram of apparatus.

\section{III. 実験結果および検討}

\section{1． 黒鉛分散 $\mathrm{Al}$ および $\mathrm{Cu}$ 鋳造合金の減衰能}

Fig.2 は $\mathrm{Ni}$ メッキした粒径 24〜32 メッシュの黑鉛を $\mathrm{Al}, \mathrm{A} 1-12 \% \mathrm{Si}$ 执よび $\mathrm{Al}-12 \% \mathrm{Si}-3 \% \mathrm{Cu}-0.3 \% \mathrm{Mg}$ 合金溶 


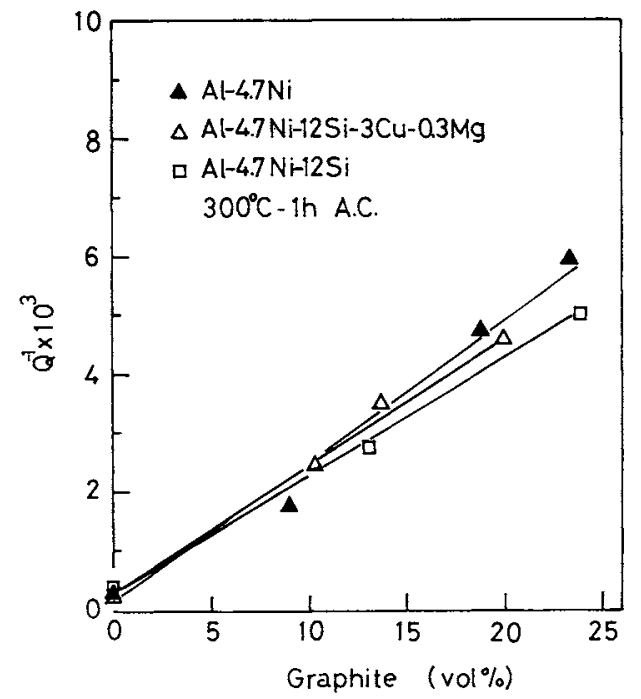

Fig.2 Effect of graphite on the damping capacity of Al casting alloys.

晹に添加して鋳造した試料の Q 示す。ここで $\mathrm{Ni}$ 量は黒鉛の添加量によって変動しないよ う黒鉛の添加量が少ない場合には，あらかじ Niを溶晹 中に添加して挔補充した。な打黑鉛量が $20 \mathrm{vol} \%$ 以上 になっている場合があるのは黒鉛が鋳塊中に完全に均一に は分散してないためで，一方 Niは Al 合金中に溶出して いるので合金中の $\mathrm{Ni}$ 量としては一定である、いずれの合 金に叔て黑鉛を添加しないときには $Q^{-1}$ が約 $4 \times 10^{-4}$ と低い，しかし黑鉛量が增加するにつれて Q 的に增加し，20 vo1\% 以上の黑鉛量が約 $5 \times 10^{-3}$ 以上の值 になる。をた $Q^{-1}$ は黒鉛量が同じであれば，基質の合金組 成が異っても卧注同じ值を示すことがわかる。

Fig.3は $\mathrm{Cu}$ メッレた24〜32メッシュの黑鉛を Cu$27.5 \% \mathrm{Mn}, \mathrm{Cu}-5 \% \mathrm{Sn}-5 \% \mathrm{Zn}-0.8 \% \mathrm{Ti}$ おび Cu-5\% $\mathrm{Sn}-$

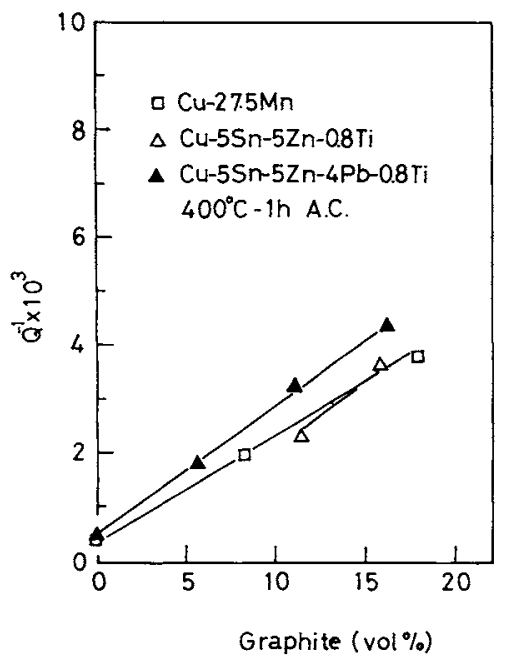

Fig.3 Effect of graphite on the damping capacity of $\mathrm{Cu}$ casting alloys.
$5 \% \mathrm{Zn}-4 \% \mathrm{~Pb}-0.8 \% \mathrm{Ti}$ 合金に分散させた鋳造試料の $\mathrm{Q}^{-1}$ と黒鉛量との関係である，Pbを含む $\mathrm{Cu}$ 合金では，Pb それ自体の $Q^{-1}$ が高い(15)ため全体としての ${ }^{-1}$ が他の合 金より多少高くなる傾向にあるが，しかしいずれの場合も $Q^{-1}$ は黒鉛量とともに直線的に増玑し，黒鉛を分散した基 質の合金組成にはあまり影響されない。また焦鉛を16 vol \%分散した $\mathrm{Cu}$ 合金の $Q^{-1}$ はほぼ $4 \times 10^{-3}$ となる。さらに $\mathrm{Cu}$ 合金々 $\mathrm{Al}$ 合金のQ $Q^{-1}$ 家じ墨鉛量で比較してもほぼ 同等であることがわかる，以上の結果からこれらの合金 の高いQ $Q^{-1}$ は主として黑鉛が存在することによって得ら れ，黒鉛を分散する基質の種類动よび基質の合金組成の 影響は少ないと言える。さて減衰機構から亮克ば本合金と 同じ複合型に属する片状黑鉛鋳鉄は，黒鉛が大きいほど $Q^{-1}$ が高くなると報告(9)(10)されている。そこで精径の影響 以ついて検討した結果を Fig.4k示す、陚料としては粒䅅 の異なる黒鉛を20 vol\%分散さ㳡た Al-4.7\% Ni-12\% $\mathrm{Si}$ $3 \% \mathrm{Cu}-0.3 \% \mathrm{Mg}$ 合金执よび $16 \mathrm{vol} \%$ 分散させた Cu-5\% $\mathrm{Sn}-5 \% \mathrm{Zn}-4 \% \mathrm{~Pb}-0.8 \% \mathrm{Ti}$ 合金を用いた。いずれの合金の 場合も黑鉛粒径が大きなるにつれて Q た黑鉛粒径は耐摩耗性にも影響し，黑鉛粒径を大きくする 之酎摩耗性も改善される

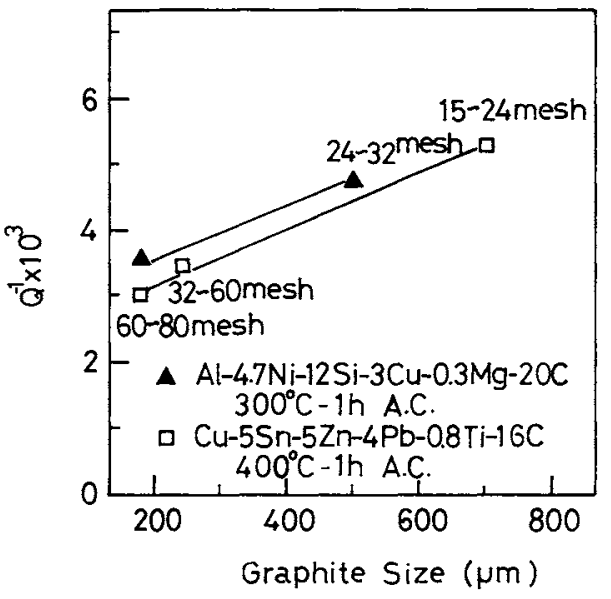

Fig.4 Graphite size dependence of damping capacity of graphite-dispersed $\mathrm{Al}$ and $\mathrm{Cu}$ casting alloys.

以上述へたよらに黒鉛分散 $A 1$ およびCu鋳造合金の $Q^{-1}$ は黒鉛量就よび大ささによって变化し，基質の種類や 基質の合金組成にはあまり影留されない。これは本合金の $Q^{-1}$ が既儿提案されたいわゆる複合型の高減衰材料の減衰 機構である基質と第 2 相との界面での摩擦 ${ }^{(15)(19)}$ あるいは 第 2 相の変形に基らくエネルギーの吸收 ${ }^{(6)(9)(19)}$ のちち, 王として後者心依存していることを示唆していると考光ら れる。し前者であるとすれば， $Q^{-1}$ は内在する黒鉛の表 面積および基質の影響を強くらけるので黒鉛の表面積汸大 きいほどすななわち同じ体積であれば粒径の小さいほど高 
くなり，また基質の種類や合金組成によりかなり変化しな ければならないからである。

次に $Q^{-1}$ の温度依存性について検討した結果を述べる。

Fig.5 は黒鉛を 9〜23 vol\% 分散させた $\mathrm{Al}$ 合金の $Q^{-1}$ の温度变化を示す．Fig.6 は黒鉛を 5 １8 vol\% 分散させ た $\mathrm{Cu}$ 合金の $Q^{-1}$ の温度变化を示す。語した本合金の減 衰機構からも予想されるように，この温度範囲ではいずれ の場合も $Q^{-1}$ の温度による変化は少ない。

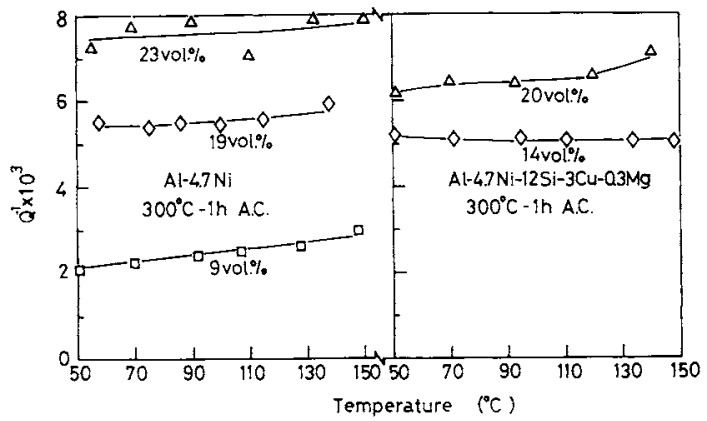

Fig.5 Temperature dependence of damping capacity of graphite-dispersed Al casting alloys.

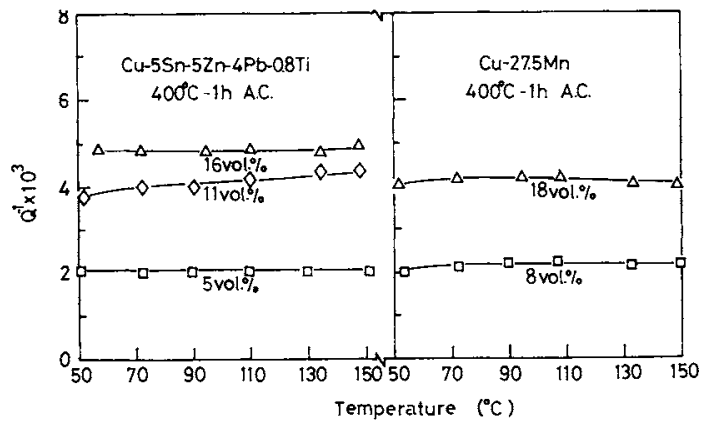

Fig.6 Temperature dependence of damping capacity of graphite-dispersed $\mathrm{Cu}$ casting alloys.

\section{2. 既知高減衰能合金の減定能}

黑鉛分散鋳造 $\mathrm{Al}$ および $\mathrm{Cu}$ 合金の $Q^{-1}$ を既知高減衰能 合金と此較するため，同じ装置を用いて $\mathrm{Mn}-\mathrm{Cu}$ 合金およ び片状黒鉛鋳鉄 FC10，FC25 などの $Q^{-1}$ を測定した。

Fig.7 は $65 \% \mathrm{Mn}-35 \% \mathrm{Cu}(\mathrm{wt} \%)$ 合金を $850^{\circ} \mathrm{C}$ にて $2 \mathrm{~h}$ 加熱保持後水冷し， $400^{\circ} \mathrm{C}$ 飞て時効したときの時効時間之 $Q^{-1}$ との関保抌よび $Q^{-1}$ の温度変化を示す。ここで温度依 存性測定は $Q^{-1}$ の最高值が得られる条件で時効した試料に ついて行った. $2 \mathrm{~h}$ の時效により $Q^{-1}$ は約 $14.5 \times 10^{-3}$ とい ら高い值になった。しかしこの合金系では既に報告(1)(2)さ れているように，昇温にともないQ

次に片状黒鉛鋳鉄 $\mathrm{FC10}$ および $\mathrm{FC} 25$ を $950^{\circ} \mathrm{C} に て 2 \mathrm{~h}$ 加熱保持後空冷 $\mathrm{L}$ ，さらに $710^{\circ} \mathrm{C} k 3 \mathrm{~h}$ 保持後，除冷す るという熱処理を施して基質をつニライト化した試料の $Q^{-1}$ を測定した．Photo.3 亿熱処理後に括けるFC10 打 よび 25 の組織を示すＦC10 执よび FC25 の黒鉛含有量
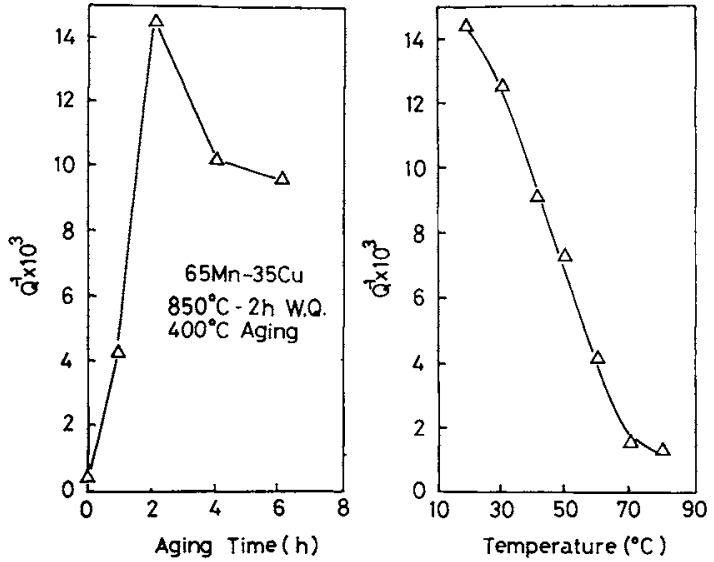

Fig.7 Effect of aging time on damping capacity in $\mathrm{Mn}-\mathrm{Cu}$ alloy and temperature-dependence of damping capacity in $\mathrm{Mn}-\mathrm{Cu}$ alloy aged for $2 \mathrm{~h}$ at $400^{\circ} \mathrm{C}$

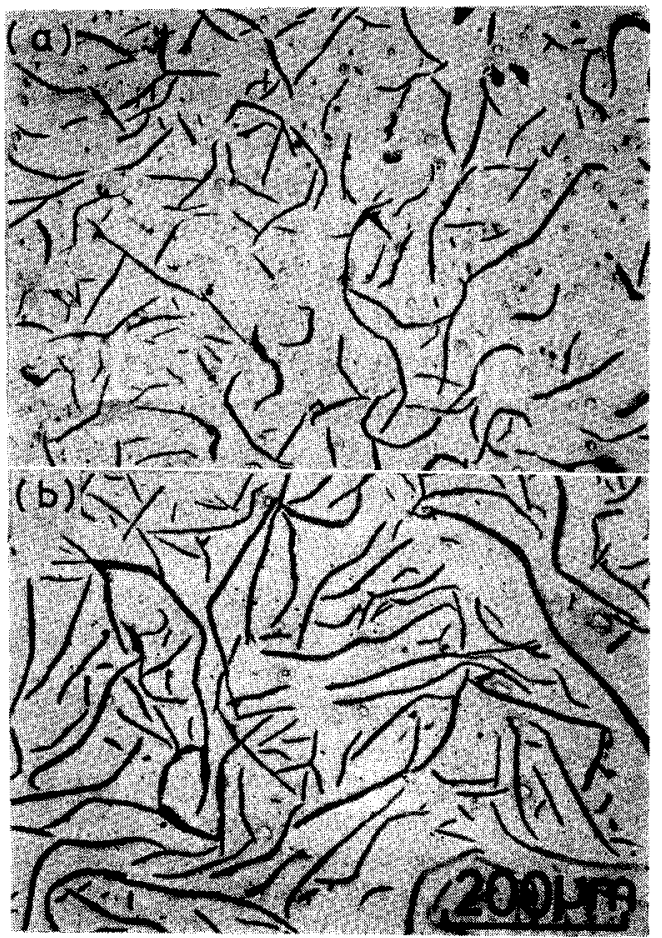

Photo.3 Microstructure of flaky graphite cast irons. (a) $\mathrm{FC} 25$, (b) $\mathrm{FC} 10$.

はそれぞれ約 13 vol\% 拉よび約 6 vol\% である。また FC 10 の基質はほぼ完全にフェライト化されていたが，FC25 の場合汇は面積比で約 $20 \%$ 程度のパーライトが認められ た.

Fig.8は上記試料の $Q^{-1}$ の温度変化を示す. 室温付近で の FC 10 の $Q^{-1}\left(4 \times 10^{-3}\right)$ は FC 25 の $Q^{-1}\left(1.5 \times 10^{-3}\right)$ に比 較して高いが，こ机は前者では後者に比較して黒鉛が大き く，しかも量が多いこと(Photo.3)および基質がフェライ 卜化して特り磁気一機械的摃失 ${ }^{(6)(24)}$ の寄与が大きいこと 


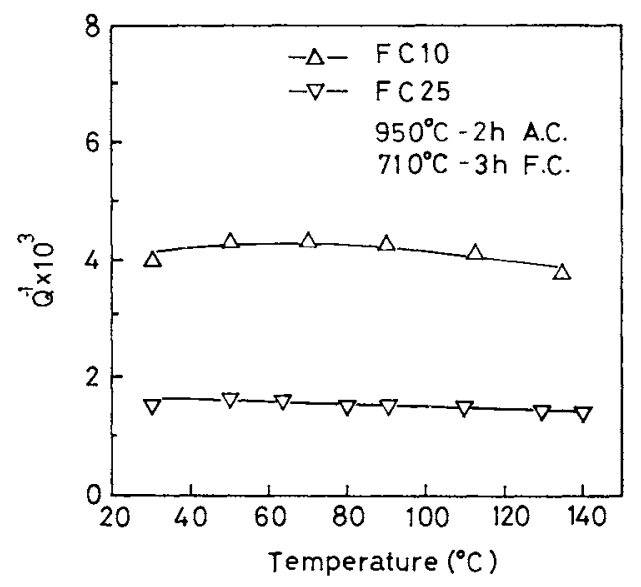

Fig.8 Temperature dependence of damping capacity of flaky graphite cast iron (FC10, FC25.)

によるものであろう、しかし，いずれの場合も $Q^{-1}$ は黒鉛 を 16〜20 vol\% 分散させた $\mathrm{Al}$ 和よび $\mathrm{Cu}$ 合金の $Q^{-1}$ より は低い、また $Q^{-1}$ は温度が高くなっても黒鉛分散 $\mathrm{A} 1$ およ び Cu 鋳造合金の場合と同様低下しない，な叔同じ体積比 で片状黑鉛鋳鉄と埋鉛分散 $\mathrm{Al}$ および Cu 鋳造合金の $Q^{-1}$ とを比較した場合，FC25 では約 $0.2 \times 10^{-3}, \mathrm{FC} 10$ では約 $1 \times 10^{-3}$ だ黑鉛分散合金よりも高い。これは組成の活注 同じ鋳鉄飞和いて黒鉛の形状が片状から球状に変化すると $Q^{-1}$ がかなり小さくなる(8)(9)ことからる推定されるよう に, FC10 打上び FC25 の場合には黒鉊が片状であるのに 対し，黒鉛分散合金では黑鉛の形状が片状というよりはむ しろ塊状に近い(Photo.1)こと括よび FC10においては基 質の磁気 一 機珹的損失 ${ }^{(6)(24)}$ の寄与があるためと考点られ る。

\section{IV. 結 言}

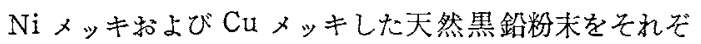
れ $\mathrm{A} 1$ 拈よび Cu 合金溶湯中に投入添加して作製した鋳造 合金ならびに $\mathrm{Mn}-\mathrm{Cu}$ 合金招よび片状墨鉛鋳鉄 FC10, FC25 の減衰能 $Q^{-1}$ を自励発振方式の静電型の横振動装置 を用いて室温から $150^{\circ} \mathrm{C}$ の温度範团で測定し, 以下の結 論を得た。

（1）黑鉛分散 $A 1$ および $\mathrm{Cu}$ 鋳造合金の $Q^{-1}$ は黑鉛量と ともにほぼ直線的に高くなる。また黒鉛を分散する基質の 種類および合金組成の影響は少ない。

（2）黒鉛を 16 vol\% 分散させた Cu 合金㧤よび $23 \%$ 分 散させた $\mathrm{A} 1$ 合金の $Q^{-1}$ はそれぞれ約 $4 \times 10^{-3}, 6 \times 10^{-3}$ で 西る。な蚍較のため測定した高減衰能合金 $65 \% \mathrm{Mn}$
$35 \% \mathrm{Cu}$ 合金の $Q^{-1}$ は室温で $14.5 \times 10^{-3}$, フニライト化し た片状黑鉛鋳鉄 FC10 和よび FC25のQ $Q^{-1}$ はそれぞれ $4 \times 10^{-3}$ 扣よび $1.5 \times 10^{-3}$ であった。

（3）黑鉛分散 $\mathrm{Al}$ 打よび $\mathrm{Cu}$ 鋳造合金の $Q^{-1}$ は黒鉛粒径 を大きくすると堌加し，また $Q^{-1}$ の温度俵存性は小さい．

本研究を行うにあたり御指導頂いた日立研究所 飯塚 富雄技術主幹ならびに機械研究所 岡田下里主管研究員, 森本庄吾主任研究員，中江秀雄主任研究員，また実験に協 カして頂いた当研究室 土屋正利氏，小室勝博氏に感謝し ます。

\section{文献}

(1) D.Birchon, D.E.Bromley and D.Healey : Met. Sci. J., 2 (1968), 41.

（2）杉本孝一，水谷啓嗣：日本金属学会誌，39(1975), 503.

(3) I. A. Arbuzova, U. S. Gavrilyuk and L.G. Khandros : Fiz. Metal. Metalloved., 27 (1969), 1126.

(4) R.Hasiguti and K.Iwasaki : J.Appl. Phys., 39 (1968), 2182 .

（5）織田貞四郎, 中村 誠：日本金属学会会報，6(1967), 729 .

（6）松井 啓，松野 亮，木津文生，高橋 睦，菅野 秀婎：日本金属学会誌，40(1976)，1062.

(7) M.A.O.Fox and R.D.A.Adams : J.Iron Steel Inst., 210(1972), 527 .

(8) R.D.Adams and M.A.D.Fox : J.Iron Steel Inst., 211 (1973), 37.

(9) M.A.O.Fox and R.D.Adams : J.Mech. Eng. Sci., 15(1973), 81 .

(10) T.Morooka, Y.Sugiyama and S.Ito : Modern Casting, $53(1968), 3,90$.

（11）松井 啓，高橋 睦，寄高政史：鋳物, 45(1973)， 508.

(12) A.S. Nowick : J.App1. Phys., 22(1951), 952.

(13) G.F.Weissmann : Proc. ASTM, 58(1958), 869.

(14) K.Sugimoto, K.Niiya, T.Okamoto and K. Kishitake : Trans. JIM, 18(1977), 277.

(15) 柇本孝一：鉄と鋼，14(1974)，2204.

（16）增本 量, 沢谷昭八, 此内正勝：日本金属学会誌, 41 (1977), 820.

（17）增本 量, 沢谷昭八, 比内正勝：日本金属学会誌, $42(1978), 337$.

（18）森本庄吾, 中江秀雄：日本金属学会会報, 17 (1978), 126.

(19) P.K.Rohatgi, N.Murali, H.R.Shetty and R. Chandrashekhar : Mater Sci. Eng., 26(1976), $115 \sim 122$.

(20) 諏訪正輝，小室勝博，添野浩：日本金属学会誌， $40(1976), 1074$.

(21) 諏訪正輝, 小室勝博, 添野 浩：日本金属学会誌, $41(1977), 511$.

(22) 諏訪正輝，小室勝博，添野 浩：日本金属学会誌。 $42(1978), 1034$.

（23）日本金属学会編：材料検査法，(1959)， p.28.

（24）杉本孝一，茨木正雄：日本金属学会誌，31 (1967)， 67. 